\title{
RESEARCH
}

\section{The Justicization of Politics: Constitutionalism and Democracy in Germany after 1949}

\author{
Verena Frick \\ Georg-August-University of Göttingen, DE \\ verena.frick@uni-goettingen.de
}

By engaging with the historiography of German constitutionalism after 1949, this article reconstructs a profound change of the meaning of the concept of constitution. The constitution evolved from a rather formal and provisional instrument of government to the just value order of politics, which scholars worldwide have celebrated as the value model of constitutionalism. The article critically examines the democratic consequences of this justicization of politics and disentangles the relationship between law and politics within German constitutional thinking by tracing its traditions and transformations back to scholarly debates and early Constitutional Court's landmark decisions.

Keywords: Constitutionalism; Democracy; Germany; Constitutional Court; Law and Politics; Stability

\section{Introduction}

The adoption of the German Basic Law in 1949 turned a new page in the history of modern constitutionalism. Constitutional lawyers worldwide have referred to the Basic Law as 'one of the world's most celebrated constitutions' (Kommers \& Miller 2012, 1). During the last seventy years, the Basic Law did not only serve as a model for constitution-making, but also led to a turning point in theorizing constitutionalism. As constitutional lawyers highlight, it paradigmatically embodies a new, so-called value-model of constitutionalism (Rensmann 2006, 259) and thereby marks a 'momentous transformation' (Somek 2014, 1) in the history of modern constitutionalism. At the heart of the Basic Law's attractiveness is the claim, first and foremost advanced by the Federal Constitutional Court (FCC) together with German constitutional lawyers, 'not only to create a system of governance but also to foster a secure and preferred way of life' (Kommers \& Miller 2012, 47). The idea was strikingly new that the constitution provides meaningful guidelines for a good and just democratic polity via fundamental rights. The Basic Law's strong impact on the German polity is a peculiarity of German constitutionalism, not only in the formal sense of organizing political power but in the substantive sense of shaping politics via constitutional values. The famous concept of 'constitutional patriotism' (Müller 2007) captures this close connection between politics and the constitution within German political thought in a nutshell. 
However, the concept of constitutional patriotism itself refers to a profound ambiguity in German constitutionalism that is frequently ignored: Even though constitutional rhetoric and constitutional values are omnipresent in every day German politics, constitutional practice is highly formal, juridical and guarded by judges and constitutional lawyers. The widely acknowledged success story of German constitutionalism is first and foremost a legal one that equates constitutionalism with rights, courts and juridical doctrines. Therefore, not surprisingly, recent research on German constitutionalism focused exclusively on legal topics like the rise of the FCC, the value-model of the constitution (Collings 2015; Hailbronner 2015; Rensmann 2006), the increasing significance of fundamental rights, and the proportionality test (Somek 2014; Huscroft et al. 2014; Kumm 2007). By contrast, insufficient scholarly attention has been devoted to the relationship between law and politics within German constitutionalism.

This article disentangles the relationship between law and politics within German constitutionalism and localises it beyond the dominant "juridification of the political vs. politicization of law' battle lines. Besides all the international academic praise for the German value-model of constitutionalism, constitutional scholars often neglect that value constitutionalism may come along with democratic costs. I shall argue that the relationship between law and politics within contemporary German constitutionalism is best understood as a normativist 'justicization' of politics through constitutional law. By justicization I mean not only the rather formal 'ever-accelerating reliance on courts and judicial means for addressing ... public policy questions' (Hirschl 2006, 721) - frequently connected with the notion of juridification - but the penetration of politics by a substantial concept of constitutional rights as principles of political justice. In consequence, controversies over such questions tend to be solved via constitutional interpretation bypassing democratic dispute and conflict settlement. This development goes hand in hand with a deep-rooted distrust in procedural democracy. Thus, German constitutionalism at the same time stabilizes and restricts politics via superior constitutional values. I arrive at this conclusion from a critical account of contemporary German constitutionalism that traces the historiography of German constitutional thinking back to scholarly debates and the Constitutional Court's landmark decisions during the first two decades after 1949. During that period, the FCC worked together with leading constitutional scholars (the so-called Staatsrechtslehre) intensively on re-establishing the procedural rule of law as substantive rule of the good law - with the constitutional value order in the very centre. In this formative phase, the course for German constitutionalism has been set.

The article proceeds as follows: The first two sections outline the conceptual tenets underlying German constitutionalism regarding the relationship between law and politics. In section 1 , the article starts with reconstructing the trend towards justicization as part of a broader understanding of constitutionalism as comprehensive concept of political stabilization that emerged in Germany after the end of National Socialism. Section 2 proceeds by distinguishing three core dimensions of German constitutionalism - guardianship, value-constitutionalism and juridical epistocracy - and traces the interplay between law and politics across these dimensions. After those two conceptual sections, the article turns to theorising German constitutionalism. Section 3 refers back to the distinction between legal and political constitutionalism as recently stressed by authors such as Richard Bellamy or Jeremy Waldron and locates German constitutionalism within a legal-normativist model. The final section concludes with a brief outlook on the future of German constitutionalism and highlights evidence for a gentle change towards political constitutionalism. 


\section{Constitutionalism and Political Stabilization after 1945}

Recently, Andreas Voßkuhle, acting president of the FCC, described the Basic Law as a 'constitution of the middle' (Voßkuhle 2016). As he pointed out, Germany's constitutional practice after World War II was strongly committed to the ideas of moderation, compromise, and restrain. According to Voßkuhle, from the very beginning, Germany's constitutional order was influenced by the idea of strengthening and preserving the middle. This insight into German constitutional thinking after 1945 is remarkable in several ways: The middle as a political concept refers to what has been labelled the post-war German idea of political stabilization (Münkler 2010). German politicians have been preferably addressing themselves to the middle, and party politics were all about gaining the middle. Calling the Basic Law a constitution of the middle therefore draws an analogy between this particular idea of political stabilization and the crucial role the constitution is assumed to play therein.

Indeed, stability was the most pressing political issue after 1945 (Müller 2011, 125) and applied equally and especially to constitutional matters. The failure of the Weimar Constitution posed heavy burdens on German constitutionalism after 1945 - or as Werner Weber put it: 'The Weimar constitution was like a deceased ancestor's ghost depressing the parliamentary council's proceedings' (Weber 1949, 5). The Basic Law must be understood as a post-dictatorial constitution and as such, it is shaped more by fear of the political process than by trust in political practice. During their work on the Basic Law, the framers were first and foremost concerned about constraining political domination via constitutional law. In this situation, the main task was political stability and it was supposed to be achieved through law. Therefore, a wide range of legal measures of constitutional self-stabilization were incorporated into the Basic Law to underline that 'Bonn is not Weimar' - as the famous mantra went. The best known among these measures are the supremacy of fundamental rights not only over ordinary law but over the three branches of government, the adoption of an eternity clause and the exclusion of certain rights and principles from constitutional amendment, different instruments of militant democracy like party ban and forfeiture of fundamental rights and the constructive vote of no confidence against the chancellor instead of a just simple vote of no confidence.

Even more important than those legal provisions was a shift in constitutional thinking initiated by the FCC itself. Originally, constitutions became meaningful as instruments of government. Notably in the American constitutional tradition, the constitution serves as an organizational framework for the legitimate exercise of political power. At the heart of the organizational model lies the idea that constitutions are formal instruments for ordering politics, establishing institutions and circumscribing competences by legal means. Matters of shared beliefs or political guidelines are considered as beyond their reach and instead form an essential part of politics. However, the strategy of the FCC was to distinguish the Basic Law sharply from a purely organizational constitution concept. From the very beginning of its jurisdiction, it has been interpreting the Basic Law as a 'unified order of political and social life' (BVerfGE [1953] 2, 380 [403]) out of which meaningful guidelines, principles and values for the order of society can be drawn (BVerfGE [1951] 1, 14 [32]; [1962] 15, 167 [194]; [1965] 19, 206 [220]; [1972] 34, 165 [183]; [1974] 39, 1 [67]; [1981] 59, 360 [379]; [1987] 77,1 [44]; [1998] 99, 1 [11]). Under the jurisdiction of the Constitutional Court, the Basic Law has been evolving into the substantial order of the polity. The Court has captured this overall claim for constitutional ubiquity in an early landmark decision with the catchy notion of 'radiation' (BVerfGE [1958] 7, 198 [29]).

The reason behind this was a thoroughly extralegal one. It is particularly revealing to take a closer look at the court's decisions, in which the idea of the constitution as a meaningful 
entity that preserves political standards was developed. One will quickly notice that the ideas of entity, unity or values do not belong to the essential parts of decision-making from a strict legal perspective. As commentators were quick to point out, the court would have been able to justify its decisions in purely dogmatic terms (Lübbe-Wolff 2016). Thus, one cannot escape the conclusion that the invocation of these notions rather takes the form of rhetoric, but a powerful one at that.

Among those elements, maybe the most powerful one was the concept of integration. The Federal Constitutional Court picked up the concept of integration in several of its early decisions: it discussed, for example, the integrative role of political parties (BVerfGE [1952] 1, 208 [225]), the election's integrative function (BVerfGE [1957] 6, 84 [94]; [1962] 14, 121 [135]) or declared that 'for the first time in Germany's history, the process of political integration happens with assistance of a Constitutional Court' (Leibholz 1957, 111). Altogether, the familiar dictum of integration by constitution became somewhat like a leitmotif for German constitutionalism after 1949. As Michael Stolleis $(2005,294)$ has noticed, "the concept of integration was that kind of intellectual nutrition everybody in public and in constitutional theory was longing for. Everybody, except the communists, should be and wanted to be integrated.'

The Constitutional Court popularized the idea of integration by constitution and in doing so, drew heavily on ideas from German constitutional lawyers. Indeed, the idea of integration by constitution is rooted deeply in German constitutional theory as developed during the Weimar Republic. It was Rudolf Smend ([1928] 2005) who formulated a theory of integration wherein the constitution was 'the legal ordering of the process of integration; its purpose was to stimulate and channel this process, keep open opportunities for further development, and finally, normativize values upon which citizens agree' (Korioth 2000, 210). Initially focused on the state, Smend's influential students like Konrad Hesse, Horst Ehmke, or Peter Häberle developed the theory of integration further and turned it into a substantive constitutional theory for the Basic Law, which declared forming and conserving political unity as the constitution's prime tasks. The central concern of the so-called Smend school of constitutional theory (Günther 2004) was formulated by Konrad Hesse ([1959] 1978, 80), professor of public law and later judge at the FCC, in his inaugural lecture in 1959: What does it need for a constitution to gain normative power? The answer of the Smend school was unanimous: a will to constitution must be established throughout the polity and everybody should be integrated into 'the open society of constitutional interpreters', as Peter Häberle ([1975] 2018) famously put it.

In somewhat polemical terms, the theory of integration has been called an 'official state doctrine' of the Federal Republic of Germany (van Ooyen 2008, 55). However, there may well be some truth in this sentiment. The concept of integration by constitution as popularized in German constitutionalism presupposes that, as Dieter Grimm holds, the constitution is subject to expectations that extend far beyond its normative regulatory function. People expect the constitution to unify their society as a polity ... The constitution is regarded as a guarantee of the fundamental consensus that is necessary for social cohesion' (Grimm 2005, 194). The Constitutional Court and the Smend School of constitutional theory worked hand in hand to reframe the concept of the constitution in the sense of a unified material order of politics and to develop the idea that the constitutions aids the establishment and maintenance of a good polity. Considering that from the mid-1950s through much of the 1960s, large discrepancies between the Basic Law's normative claims and their realization in much of German law and society actually existed (Hailbronner 2014, 643), it becomes obvious that the FCC and the Smend School followed an agenda of political change by legal means. The development of a rhetoric of integration in constitutional interpretation and constitutional theory refers directly to the Basic Law's radiation into politics and must be considered in the context of a postwar quest for political legitimacy and stability (Frick 2018, 32). 


\section{Core Dimensions of German Constitutionalism}

Given the fact that historians today describe Germany's political culture as 'constitutioncentered' (Herbert 2006), one can draw the conclusion that both the Constitutional Court and the Smend School of constitutional theory succeeded with their strategy of integration by constitution. West Germany's political consolidation was guided by the implementation of constitutional principles. The constitutional impact on politics was therefore substantial. But how could this impact endure? Which factors sustained the rise of the Basic Law as integrative constitution? This section investigates the question of path dependency in German constitutional thinking. I focus on three dimensions which have been perpetuating the focus on stability and stabilization within German constitutionalism until today; these dimensions touch on institutional questions concerning the guardian of the constitution, on dogmatic innovations, especially fundamental rights as values, and on the epistemic authority of jurists.

\section{Guardianship}

The most lasting effect on the development of German constitutionalism had the idea to ensure constitutional supremacy via a constitutional court, an institution alien until that point within Germany's constitutional tradition. The success story of postwar German constitutionalism would be unimaginable without the FCC. From the very beginning, the court understood itself as an institution sui generis and enthroned itself in the 1950s as the supreme guardian of the constitution. The framers of the constitution had left the question of the new institution's status open. Thus, it was the court that empowered itself in the so-called status memo as a strong independent constitutional body. The notion of the FCC as guardian has become something like its guiding idea. At the same time, the court ended older discussions about the nature and scope of constitutional review fought without a clear winner or loser mainly between Carl Schmitt and Hans Kelsen in the 1930s (Vinx 2015).

It is instructive to look into the status memo that the court submitted on its own initiative to the federal government in 1952 and wherein the court declared precisely what it meant for it to serve as guardian of the constitution. ${ }^{1}$ These ideas shape the court's self-perception as well as its perception by others until today. The memorandum is closely linked to the person of Gerhard Leibholz, professor of constitutional law and judge at the FCC from the very beginning, who wrote these influential passages and who was eventually able to convince his colleagues in the court to follow his interpretation of the concept of guardianship. Reading the memorandum, one gets a clear impression of the court's active self-understanding and its claim for institutional independence: Leibholz claimed a crucial role for the FCC in stabilizing the state and integrating the polity. According to Leibholz, judgments should serve

\footnotetext{
1 When the Federal Constitutional Court started its work on 9 September 1951, its status was not clear at all. Would it serve as a higher federal court specialized on constitutional matters, but institutionally equal to the other higher federal courts as for example the Federal Court of Justice? Or should it serve as an institution sui generis, separated from the regular judiciary and equal to the other constitutional organs with budgetary and institutional independence? In the beginning, the Court stood under the supervisory authority of the Ministry of Justice which controlled its internal administration like salary and staffing. On 27 June 1952, nine months after the Court opened its doors, the Court submitted on its own initiative the so-called status memo to the other constitutional organs. Therein the Court declared that its current institutional position was unconstitutional. The Court claimed in its report that it "must be addressed, not only as the head of judicial authority and in its capacity as guardian and guarantor of the constitution, but also as constitutional organ, endowed with supreme authority, which politically as well as for purposes of constitutional law must be placed beside the Bundestag, the Bundesrat, the federal government and the federal president' (Translation by Collings 2015, 11-12). The status memo became ground-breaking for the Court and put the federal government under pressure. In the end, the Court was victorious over the federal government (for more details see: Collings 2015, 5-14).
} 
'the political integration of the whole' and contribute to ensure and preserve political unity (Leibholz 1957, 111).

Yet, regarding the court's position between law and politics, Leibholz remained contradictory. He saw clearly that decisions of the court would always have an impact on politics, as constitutional law is essentially political law. But at the same time, he understood the FCC as a court proper, that is, an institution which exclusively follows the juridical maxims of independence and impartiality, thus making decisions based purely on law and legal doctrines, not on political considerations. Thus, Leibholz rooted the settled practice of the court not only within the legal system but assured at the same time the court's autonomy from politics. A couple of years later, in an article entitled 'The Federal Constitutional Court between Law and Politics' (1974), Leibholz clarified further his interpretation of the relationship between law and politics underlying his concept of the guardian of the constitution. Leibholz was convinced that there is an irreconcilable difference between law and politics. Politics are, as he wrote, from their very nature dynamic and irrational, whereas law is from its very nature static and rational which means, that law's purpose is to control the vital forces of politics (Leibholz 1974, 397).

Leibholz's understanding of the nature of law and politics fits perfectly with what Stephen Holmes has referred to many years later as the notion of 'negative constitutionalism'. According to Holmes, constitutional thinking in general is dominated by a negative constitutionalism, which captures constitutions only as 'preventive or inhibitory devices' and settles their major task in constraining politics (Holmes 1995, 6). Furthermore, negative constitutionalism presupposes a sceptic view on human beings, especially on politicians. They resemble, as Holmes metaphorically notes, rampant drunk Peter, as opposed to constitutional law as his reasonable alter ego, sober Peter (Holmes 1995, 135). Hence, in the extreme, negative constitutionalism appears to imply a kind of mental incapacity of politics. Regardless of whether Leibholz's concept really would have gone that far, he clearly reveals an unpolitical reading of law which presupposes law's epistemic supremacy over politics - and consequently the supremacy of whoever is responsible for the ultimate interpretation of constitutional law. Therefore, Leibholz's belief in law's epistemic supremacy corresponds seamlessly with the institutional supremacy of the guardian of the constitution.

Of course, the Basic Law itself gave birth to the idea of supremacy of the constitution, stating in article one that fundamental rights shall bind the legislature, the executive, and the judiciary as directly applicable law and in consequence overruling legislative acts of parliament. Translated into institutional questions and considering the fact that the FCC appointed itself the sole guardian of the constitution, this sentence stipulates the supremacy of the constitutional court over the democratically elected parliament (Kommers \& Miller 2012, 76). Dieter Grimm summarizes that 'there can be no doubt that, in the end, this leads to a loss of parliamentary power and a gain of court power, yet in the name of human rights. It is more the sort of freedom guaranteed by human rights that the sort of freedom guaranteed by democratic participation which prevails in this system' (Grimm 1994, 295; see also: Böckenförde [1999] 2017). Regarding the court's supremacy over parliament, it may seem surprising that the counter-majoritarian problem did not gain powerful traction within constitutional discourse (Möllers 2014) $)^{2}$ at least compared to the dominant narrative, which describes the court as 'father of second German democracy' (Schönberger 2011, 27). As opposed to the United States, where the judicial review of legislative laws (i.e. the competence of the Supreme Court to overrule decisions of the democratic majority) recurrently provokes intense debates on

\footnotetext{
${ }^{2}$ For some of the few exceptions see Landfried 1994 and Maus 2004.
} 
the counter-majoritarian difficulty of constitutional review and the democratic legitimacy of constitutional review in general (Ely 1980; Tushnet 2000; Waldron [2006] 2016).

By contrast, the idea of constitutional supremacy over parliamentary law and its institutional equivalent stand paradigmatically for a particular understanding of democracy that prevailed all around postwar Western Europe, which Jan-Werner Müller has described as 'constrained democracy'. This form of democracy is 'deeply imprinted with a distrust of popular sovereignty - in fact, even distrust of traditional parliamentary sovereignty' and, by contrast, shifts political power and competences to unelected, more expert driven institutions to balance and check parliaments (Müller 2011, 5). Considering that stability was referred to as the political 'lodestar' (Müller 2011, 128) of Western European democratization after 1945, the idea of guardianship as developed by Leibholz and the Federal Constitutional Court in the status memo was to provide stability and rationality for irrational and uncontrollable politics and in doing so, guiding West Germany on the road to democracy.

\section{Value-Constitutionalism}

One can hardly ignore how successful this strategy was. In retrospect, observers from Germany and abroad celebrate the Federal Constitutional Court as a 'harbinger and defender of democracy' (Collings 2015, XXXV) by stressing the court's impact on the consolidation of democracy (Kneip 2016). It was the Constitutional Court, which pointed the way for reestablishing democracy in Germany via its emphasis on fundamental rights. Maybe the most important and surely the most recognized step in this direction was the spectacular contouring of the idea of an objective order of constitutional values in several of its early landmark decisions. The following sentences out of the Lüth case belong to the probably most cited ones ever:

'The primary purpose of the basic rights is to safeguard the liberties of the individual against interferences by public authority. ... It is equally true, however, that the Basic Law is not value-neutral document. Its section on basic rights establishes an objective order of values, and this order strongly reinforces the effective power of basic rights. This value system, which centers upon dignity of the human personality developing freely within social community, must be looked upon as a fundamental constitutional decision affecting all spheres of law, both public and private. It serves as a yardstick for measuring and assessing all actions in the areas of legislation, public administration, and adjudication.' (BVerfGE [1958] 7, 198; Translation by Kommers and Miller 2012, 443-444)

Proclaiming that fundamental rights are not only directed against state intervention but also guarantee an objective order of values, the Constitutional Court lay the foundation for a farreaching process of so-called constitutionalization. As objective norms, fundamental rights do not only apply to the vertical relationship between public authorities and individuals, but also radiate in horizontal perspective onto the relationship between individual right-holders and third parties whose behavior might threaten individual rights and therefore might raise claims against public authorities to intervene on behalf of right-holders (Böckenförde [1990] 2017a; Grimm 2016; Calliess 2014). Hence, due to the radiation thesis, every ordinary law can be judged from a constitutional perspective and every institution concerned with lawmaking receives constitutional guidelines. In sum, starting with the Lüth case, the claim for objectiveness of fundamental rights has been providing a jurisprudential resource "to constitutionalize all political and legal conflicts - it constrains and guides their resolution in the name of constitutional rights' (Kumm 2006, 344). 
From a legal-dogmatic perspective, notably the fact that the Court interpreted fundamental rights as objective norms was groundbreaking as it was likely to impose legal duties on the state and to force state institutions to create and maintain the conditions for an effective realization of fundamental rights (Kommers and Miller 2012, 60). Furthermore, the Lüth case contained a second important claim: the idea of a normative order of constitutional values. In legal-dogmatic terms, the benefit of the idea of values was rather poorly received compared to the idea of objectiveness. Immediately after being proclaimed, heavy criticisms were raised. Carl Schmitt's verdict of a 'tyranny of values' ([1979] 2018) was perhaps the harshest criticism but by far not the only one (particularly prominent: Böckenförde [1990] 2017b). The prevailing legal opinion among the Staatsrechtslehre up until today holds that the concept of values is something like a constitutional Arcanum, which adds nothing of substance to the court's decisions.

Against this background, the persistence of the idea of constitutional values in German constitutional thinking is somewhat perplexing. Up to this day, constitutional lawyers from very different camps habitually employ the idea and refer to the Basic Law as a prototype of the value model of constitutionalism. This holds also true for constitutional theory, where recent works describe the German constitution as an order of political justice and fairness. For example, according to Uwe Volkmann, the constitution's main task is to store, preserve, and foster society's basic assumptions of justice and fairness (Volkmann 2013). One can observe here the unfolding of a second, political meaning of constitutions, which is embedded in the idea of a normative order of values: At the core of the value model is the idea that constitutions are not only instruments of government but enshrine the idea of a good and just polity (Frick 2019, 31).

The rhetoric of values was part of a powerful constitutional strategy to commit postwar Germany to the values of liberal democracy, especially partisanship. ${ }^{3}$ In this respect, it is particularly revealing to take a closer look at the judgments where the concept of values first appeared, namely party ban cases ${ }^{4}$ and the Lüth case - all three landmark decisions for constitutionalism in Germany. What they have in common is their importance for democratic self-assurance after 1945. In the SRP case, the Court opposed the constitutional value order directly to totalitarianism and specified the principles of the free democratic basic order. The Court held: 'The constitutional order is value-based. It is the opposite of the total state which rejects human dignity, freedom and equality in terms of absolute power.' (BVerfGE [1952] 2, 1 [12]; my translation) A similar argument was given in the proceedings concerning the prohibition of the Communist Party. The Court rejected any sort of normative relativism and declared that certain principles are 'recognized as absolute values once they have been adopted democratically' (BVerfGE [1956] 5, 85 [139]; my translation). Here the court underlined the young democracy's absolute will to self-assert against past and present totalitarianism. The court legitimizes the democratic order by a reflection on its basic values and links legitimacy with constitutional values.

\footnotetext{
${ }^{3}$ What might at first sight seem contradictory, the party ban as indicator for democratization, reveals the fundamental shift towards liberal democracy that the FCC promoted after 1949. By banning, for example, the Socialist Reich Party, successor of the NDSAP, the FCC affirmed unambiguously partisanship as an unalienable part of modern democratic reality - a statement which was everything else than self-evident given the distrust of parties during the Weimar Republic.

${ }^{4}$ In 1952 the Federal Constitutional Court banned the Socialist Reich Party, successor of the NSDAP, and in 1956 the German Communist Party (see: BVerfGE [1952] 2,1 - SRP case; BVerfGE [1956] 5, 85 - KPD case). Up to these days, these were the only two successful party bans in the history of the Federal Republic. All political achievements to ban the extreme right-wing National Democratic Party (NPD) failed before the Constitutional Court (see for the 2017 decision: BVerfGE [2017] 144, 20 and for the 2003 decision: BVerfGE [2003] 107, 339).
} 
By incorporating constitutional values in constitutional doctrine, one can argue that the FCC intended to link the extralegal resource of morality and values with constitutional law - a strategy that Michaela Hailbronner has recently called 'value formalism' and which she compared with a transformative concept of constitutional law that aims at shaping society and politics constitutionally (Hailbronner 2014, 644). With that in mind, one can conclude that the concept of constitutional values stands for more than legal ordering. Rather, it is about giving meaning to politics. This path towards value constitutionalism has been already opened up earlier by the Universal Declaration of Human Rights in 1948. German framers and constitutional lawyers 'wholeheartedly embraced' the idea of unalienable values and furthermore combined it 'with one of the greatest achievements of US constitutionalism, the power of judicial review' (Rensmann 2006, 261). After 1945, re-establishing the procedural rule of law meant first and foremost the establishment of a substantive rule of the good law - and Germany was the first to incorporate that idea in national constitutional law. Today, it may well have become 'the preferred model of constitutional governance' (Kommers 2002, 63; Ackerman 1997, 773) as many states have been following the German example, for example Spain, Portugal, South-Africa, Chile, and a number of Central and Eastern Europe, which all shared similar challenges to overcome a regime of injustice.

This shift in constitutional thinking can hardly be overestimated. Regarding the German example, we are able to study the emergence of a new concept of constitutionalism within Western constitutional history. For Alexander Somek, the adoption of the Basic Law marks paradigmatically a fundamental transformation in modern constitutionalism from 'policing the exercise of public powers to the realization of fundamental rights' $(2014,82)$. Constitutional values not only impose guidelines on the legislator but might eventually be enforced constitutionally and therefore juridically against the legislator. However, that comes along with democratic costs. Interwoven into the idea of value constitutionalism is a deep-rooted distrust in procedural democracy. In conclusion, one may hold that democratic politics fulfills the task of realizing a program of constitutional justice under the surveillance of a powerful guardian of the constitution.

\section{Juridical Epistocracy}

Value constitutionalism turned out to be a successful strategy of reinforcing the legitimacy of the democratic order and to raise the political importance of the constitution and the Constitutional Court at the same time. Over the last 70 years, the Basic Law turned gradually into something that Mattias Kumm has labelled a 'total constitution'. In his words: 'The constitution serves as a guide and imposes substantive constraints on the resolution of any and every political question. The validity of any and every political decision is subject to potential challenge before a constitutional court that, under the guise of adjudicating constitutional rights provisions, will assess whether such an act is supported by good reasons' (Kumm 2006, 343). Therefore, one cannot ignore that German politics are substantively shaped and affected via the constitution and its implementation. Drawing from that the conclusion that constitutional questions are highly politicized and controversial in public would be misguided. Quite the contrary, the impact of constitutional law on politics is far-reaching, but without being political in itself.

To a great extent, German constitutionalism is capable of stabilizing and shaping politics because it follows not a political, but a juridical logic. Far and foremost, this has something to do with the manner in which German courts and lawyers treat law. Germany's legal culture has been traditionally emphasizing expertise and an academic conception of law, which the continuous tradition of dogmatics in jurisprudence and 'legal science' capture in a nutshell (Frick 2018, 152). The power of dogmatics as a particular methodological approach is the 
key to understand German constitutionalism. Constitutional lawyers of the Staatsrechtslehre tradition and the FCC - which is itself to a considerable extent staffed with professors of constitutional law - both share the belief that applicable law can be conceived of in a coherent system of concepts, institutions, and rules labeled as dogmatics. Practically spoken, that means that academia and courts divide the labor (Lepsius 2012): in their findings, courts interpret the constitution and produce legal principles whereas academia systematizes and unifies those principles and aims for consistency in applicable constitutional law. Dogmatical reasoning therefore consists in linking old and new law, statute and case law as well as filling gaps within the system of law. In doing so, dogmatics are supposed to guarantee a certain rationality and to uphold the juridical claim for a comprehensive regulative power of law.

This very 'German Approach' (Schönberger 2015) comes along with a particular understanding of law: law is treated as a timeless, objective and therefore unpolitical source of law. It is supposed to exist detached from its political origin and also detached from the particular political interests, intentions and strategies that it was supposed to serve when adopted in legislation. Germany's legal culture does not understand law as a contingent political product but as an objective standard against which future politics will be measured. This concept of law comes along with particular assumptions regarding the relationship between the constitutional text and constitutional reality. While American pragmatism, for instance, 'leaves a lot to chance and circumstance, shows only little distress in constitutional ambiguity' (Kommers \& Miller 2012, 47), German perfectionism constantly strives as far as possible for an identity of the constitutional text and constitutional reality. This quest for equivalence does not mean less than a claim for juridical control over political reality. That is why Wilhelm Hennis once compared German constitutional thinking in somewhat polemical terms to a 'train schedule' ([1968] 1978, 239), which presupposes that political life follows something like a constitutional schedule. With his early critique of German constitutionalism, Hennis was one of the first who called attention to the distrust in the democratic process, which he saw enduring in German constitutionalism after 1945.

One of the most striking examples for this kind of constitutional scheduling is the famous principle of proportionality. Since the 18th century, the principle of proportionality has been a guiding principle of the German Rechtsstaat (the rule of law state), first and foremost in criminal and administrative law. After 1949, the FCC rapidly declared that every infringement of fundamental rights must equally meet the basic principle of proportionality (BVerfGE [1963] 16, 194 [202]; [1963] 17, 108 [117]; [1966] 20, 162 [187]) and must be developed step by step, following precisely tailored criteria for balancing conflicts between two rights claims or rights provision on the one side and legitimate government interests on the other. Turning to proportionality analysis, the court is able to consider the measures under review in a three-stage process of constitutional reasoning. After considering the suitability and necessity of the measure under review, the court regards it under proportionality in a narrow sense, i.e. the court weighs the benefits of the measure in question against the costs incurred by infringement of fundamental rights.

The principle of proportionality and the proportionality test are probably Germany's constitutional bestsellers. As Jud Mathews and Alec Stone Sweet observe, proportionality 'has become a centerpiece of jurisprudence' $(2011,799)$ in legal systems all around the world. Following Mathews and Stone Sweet, reasons for the proliferation of proportionality analysis are rather selfish: as it allows the use of a wide range of arguments under the guise of judicial reasoning, proportionality analysis 'has provided an important doctrinal underpinning for the rights-based expansion of judicial authority across the globe' $(2008,87)$. In this respect, one can even say that proportionality analysis only completes the constitutional court's radiation thesis of fundamental rights because it allows to place all and every government action 
under judicial supervision and therefore under the overall authority of fundamental rights, or as Somek $(2014,17)$ puts it: 'The recurring questions are whether government action has been too intrusive vis-à-vis fundamental rights or not sufficiently protective of them.'

The FCC usually makes it easy for legal scholars to identify the guiding principles of its decisions. In fact, an entire section of each of its verdicts is devoted to a detailed consideration of the decision's guiding principles, their constitutional meaning, justification, and relationship to recognized principles, regardless of the respective case (Lepsius 2011, 172). Furthermore, any given decision by the Constitutional Court is thought to have binding force for the democratic legislator beyond the respective case in question (this is ordinarily referred to as constitutional law by jurisdiction or Rechtsprechungsverfassungsrecht). The rhetoric of the Court's verdict is revealing insofar as their style resembles academic writings on constitutional law. Frequently, the Court even refers to academic work on fundamental rights and constitutional doctrine. Thus, the Court views its decisions as not only settling specific disputes, but as contributing to interpretations of the constitution, which are thought to be timeless and objective. Reversely, Staatsrechtslehre scholars treat the Constitutional Court's decisions as an integral part of constitutional meaning-making and academic literature.

Furthermore, the knowledge about those legal standards and doctrines is monopolized by jurists and constitutional lawyers. This epistemic authority may be seen to contribute to legal autonomy and an inner-juridical logic that immunizes the law, the Court, and the scholars against suspicions of politicization or political instrumentalization (Hailbronner 2014, 644). Thus, the rise of the constitution during the Bonn Republic is only comprehensible if one considers law's epistemology as an institutional factor of its own.

\section{Normativism and Legal Moralism}

The interplay between guardianship, value constitutionalism and juridical epistocracy has paved the way for a far-reaching justicization of German constitutional thinking. Today, standard encyclopedias on constitutional law and the state describe the constitution quite naturally as a 'juridification of a conception of the good community life' (Morlok 2006, 2561). Historically, this shift in constitutional thinking was neither inescapable nor fully intentional. It is instead the result of a conceptual change stemming from the changing perception and meaning of the constitution after 1945, driven by the FCC and influential constitutional lawyers. None of the developments displayed above were bound to happen. Initially, the Basic Law was sought to serve as a provisional solution for a provisional state. Already the name Basic Law was chosen to prevent cementing the division of Germany and to leave the door constitutionally open for reunification. It is no coincidence that two scholars as different as Werner Weber and Karl Loewenstein widely converged with their initial opinion on the Basic Law as a rather sober, technical document, unable to evoke pathos, emotion or any sense of community (Weber 1949; Loewenstein 1951).

Seventy years later, we know better. Rather than pure constitutional formalization and mechanization, we witnessed that constitutional law and morality got closer again. Even though natural law celebrated only a short revival during the first years after 1945 - notably in the early jurisdiction of the Federal Court of Justice - the FCC developed a perspective effectively akin to natural law with the concept of the objective order of values, which claims a higher moral authority of law within positive law. According to the FCC, fundamental rights serve as objective principles that uphold a complex standard of legal reasoning and justifiability for the whole body of positive law - a claim which was later apologetically elaborated in Robert Alexy's famous theory of constitutional rights as principles (Alexy 2009). Alexy holds that fundamental rights as principles entail a so-called optimization command, which means that inscribed into the concept of fundamental rights is a striving for fulfillment of 
the constitutionalist program. Accordingly, fundamental rights not only draw final borders for the legitimate exercise of public authority, but also contain an idea of a just polity in which fundamental rights flourish best. Furthermore, legislation may be judged according to whether it appropriately optimizes constitutional rights (Tschentscher 2014; for a critique, see Böckenförde [1990] 2017a).

It is not hard to imagine that as a consequence of this approach the interpretive power of the FCC and constitutional lawyers is likely to grow. It lies in judicial hands to prove the law's accordance with constitutionalist principles and to assure that it meets the objective constitutional order. Simultaneously, the capacity for judicial self-empowerment in the name of fundamental rights increases. As Dieter Grimm, himself a former judge at the FCC, notes in retrospect: "the Court has certainly been active in terms of unfolding and developing the constitution. It has elaborated a theory of human rights which exceeds the jurisprudence of most other countries with judicial review' (Grimm 1994, 295).

What might appear, at first sight, as rather doctrinal problems of proportionality, balancing conflicting claims and a careful weighing of rights actually entails a profound readjustment of constitutionalism and democracy after 1945. The idea of optimisation effectively assigns politics the role of merely executing a kind of constitutional programme, which is supposedly already embedded in the constitution. Constitutionalist principles are placed beyond political reach and, instead, radiate into politics. Thus, the space for democratic agency is substantively circumscribed by constitutional law and by the FCC as a 'strict but benevolent guardian of an immature democracy that didn't quite trust itself' (Schönberger 2011, 43).

Therefore, German constitutionalism is best understood as a form of legal-moral normativism. It paradigmatically represents a way of constitutional thinking that can be captured with the concept of 'legal constitutionalism', as put forward by Richard Bellamy or Jeremy Waldron. On their accounts, legal constitutionalism forms the dominant strand in constitutional thinking which equates constitutionalism with 'rights, their entrenchment in a constitutional document and their interpretation and elaboration by a supreme or constitutional court' (Bellamy 2007, 15; Waldron [2009] 2016, 23). This equation of constitutionalism with rights comes with political costs: legal constitutionalism ignores that rights and constitutions stand within the circumstances of politics and cannot be detached from a given political context. Without politics, rights would be mere claims to address rather than enforceable objects. Thus, Bellamy holds that we must acknowledge that politics always comes first and that having a right means having the capacity of enforcing the respective right institutionally. Furthermore, Bellamy and Waldron argue that we can never expect a consensus on constitutional interpretation because politics are characterized by reasonable disagreement over fundamental principles. These disagreements have to be solved within political institutions. Relying, by contrast, on legal expertise and judicial reasoning to settle disputes tries to displace politics from constitutionalism (Bellamy 2007, 4, 218; Waldron [2006] 2016, 199). Thus, scholars like Bellamy and Waldron argue for a 'political constitutionalism' which takes the mutual conditionality of law and politics serious.

The debate on legal versus political constitutionalism puts the spotlight on the interplay between law and politics within constitutionalism (Goldoni 2012, 926). It also highlights the fact that legal constitutionalism is by far the dominant framework, which seems to underpin Jan-Werner Müller's thesis that after the Second World War a new model of constrained democracy arose (Müller 2011, 128). As already mentioned before, Müller's notion of constrained democracy touches mainly on institutional matters, like the invention of powerful constitutional courts, which constrain parliamentary sovereignty by means of more technocratic, expert guided forms of counter-majoritarian governance. But beyond the rather formal question of how to divide power to impose institutional controls on legislative and executive 
authority, this article's analysis of German constitutional doctrines reveals that the initial idea of constraining democracy may also have a substantial long-term impact on politics, which is severely circumscribed via constitutional principles and values.

\section{Concluding Remarks: Crisis of the Constitution or more Political Constitutionalism?}

By engaging with the historiography of German constitutional thinking after 1949, the article has sought to reconstruct the interplay between law and politics embedded in German constitutional thinking along three core dimensions: guardianship, value-constitutionalism and juridical epistocracy. As a result, the article identified a radical conceptual change of the original meaning of the very concept of constitution from a mere instrument of government to a document enshrining the just value order of politics. The widely acknowledged success story of the Basic Law after 1949 closely reflects that shift as it comes along with a justicization of democratic politics. Therefore, democracy in Germany is not only institutionally constrained by the Federal Constitutional Court as a powerful non-majoritarian institution, but furthermore substantively guided by constitutionalist principles and values, which are placed beyond political dispute and change. This twofold strategy of constraining democracy and shaping it constitutionally, driven by the FCC and the Staatsrechtslehre, turned out to be a successful path for the stabilization of democracy after 1949. However, the article argues that the quest for political stability through constitutional law and distrust in democratic procedures are in fact two sides of the same coin.

But is this dual mechanism of stabilising and restricting still fully adequate for Germany's consolidated democracy today? In fact, several recent developments point to changes, which challenge German constitutionalism in all of the three dimensions pointed out in this article. A couple of years ago, German constitutional lawyers have been starting to complain about a crisis of the constitution. These complains draw mainly on two developments: First, scholars have identified an 'end of dogmatics' (Schlink 2007) within the FCC's jurisdiction in favour of more casuistry. Second, the claim for national constitutional ubiquity vis-à-vis politics is more and more contested due to supranational processes of constitutionalisation, which challenge the guiding role of national constitutions as well as the FCC's role as the guardian of the constitution (Frick 2018, 203). However, these erosions of doctrinal coherence only appear as a crisis from the perspective of constitutional law. From a more political perspective, one might perceive these developments as opening up spaces for political agency, as they tend to withdraw doctrinal penetration of constitutional practice.

Finally, on a different note, after 70 years of robust democracy in Germany and an ever more diverse society, the FCC has become today far more reluctant to accept constraints of the democratic process in favor of constitutional values. Instead, the court tends to remit highly controversial questions - for instance concerning religion or partisanship - to the democratic process. Paradigmatic in this regard is its latest decision on banning the extremeright NPD party (Nationaldemokratische Partei Deutschlands). While conceding that the NPD clearly violates the fundamental principles of the free democratic basic order, the FCC refused to ban the party due to its lack of potential to gain enough political traction to effectively realize its antidemocratic program (BVerfGE [2017] 144, 20 [585]). Turning away from its party ban jurisdiction of the 1950s, these days the court entrusts the democratic process with the task of confronting political extremism. In sum, we are witnessing a gentle change of contemporary constitutionalism in the direction of a more political understanding: The future of constitutionalism seems to belong to democratic governing with the constitution rather than under it. 


\section{Acknowledgements}

For valuable comments and critique on earlier drafts of this paper I wish to thank Sven Altenburger, Tobias Adler-Bartels, Tine Stein and all participants of the Workshop 20 'Should the people rule?' at the ECPR Joint Sessions 2018 in Nicosia.

\section{Competing Interests}

The author has no competing interests to declare.

\section{References}

Ackerman, Bruce. 1997. "The Rise of World Constitutionalism". Virginia Law Review 83(4): 771-797. DOI: https://doi.org/10.2307/1073748

Alexy, Robert. 2009. A Theory of Constitutional Rights. Oxford: Oxford University Press.

Bellamy, Richard. 2007. Political Constitutionalism. A Republican Defense of the Constitutionality of Democracy. Cambridge: Cambridge University Press. DOI: https://doi.org/10.1017/ CBO9780511490187

Böckenförde, Ernst-Wolfgang. [1990] 2017a. "Fundamental Rights as Constitutional Principles: On the Current State of Interpreting Fundamental Rights". In Constitutional and Political Theory. Selected Writings, edited by Mirjam Künkler, and Tine Stein, 235-265. Oxford: Oxford University Press. DOI: https://doi.org/10.1093/acprof: oso/9780198714965.003.0014

Böckenförde, Ernst-Wolfgang. [1990] 2017b. "Critique of the Value-Based Grounding of Law". In Constitutional and Political Theory. Selected Writings, edited by Mirjam Künkler, and Tine Stein, 217-234. Oxford: Oxford University Press. DOI: https://doi.org/10.1093/acpr of:oso/9780198714965.003.0013

Böckenförde, Ernst-Wolfgang. [1999] 2017. "Constitutional Jurisdiction: Structure, Organization, and Legitimation". In Constitutional and Political Theory. Selected Writings, edited by Mirjam Künkler, and Tine Stein, 186-205. Oxford: Oxford University Press. DOI: https:// doi.org/10.1093/acprof:oso/9780198714965.003.0011

Calliess, Christian. 2014. "Dimensions of Fundamental Rights - Duty to Respect v. Duty to Protect". In Debates in German Public Law, edited by Hermann Pünder, and Christian Waldhoff, 27-42. London: Hart Publishing.

Collings, Justin. 2015. Democracy's Guardians. A History of the German Federal Constitutional Court, 1951-2001. Oxford: Oxford University Press. DOI: https://doi.org/10.1093/acprof: oso/9780198753377.001.0001

Ely, Johan Hart. 1980. Democracy and Distrust. A Theory of Judicial Review. Cambridge (Mass.): Harvard University Press.

Frick, Verena. 2018. Die Staatsrechtslehre im Streit um ihren Gegenstand. Die Staats- und Verfassungsdebatten seit 1979. Tübingen: Mohr Siebeck. DOI: https://doi.org/10.1628/9783-16-156167-2

Frick, Verena. 2019. "Abschied von der Ordnung. Zur Ideengeschichte des Verfassungsdenkens angesichts ihrer schwindenden Normativität". German Political Science Quarterly 60(1): 21-43. DOI: https://doi.org/10.1007/s11615-018-0129-1

Goldoni, Marco. 2012. "Two internal critics of political constitutionalism". International Journal of Constitutional Law 10(4): 926-949. DOI: https://doi.org/10.1093/icon/mos033

Grimm, Dieter. 1994. "Human Rights and Judicial Review in Germany". In Human Rights and Judicial Review. A comparative perspective, edited by David M. Beatty, 267-295. Dordrecht/Boston/London: Martinus Nijhoff Publishers.

Grimm, Dieter. 2005. "Integration by Constitution". International Journal of Constitutional Law 3(2-3): 193-208. DOI: https://doi.org/10.1093/icon/moi014

Grimm, Dieter. 2016. Constitutionalism: Past, Present, Future. Oxford: Oxford University Press. 
Häberle, Peter. [1975] 2018. “'The open society of constitutional interpreters' - A contribution to a pluralistic and 'procedural' constitutional interpretation". In Peter Häberle on Constitutional Theory. Constitution as Culture and the Open Society of Constitutional Interpreters, edited by Markus Kotzur, 129-166. Baden-Baden: Nomos. DOI: https://doi. org/10.5771/9783845289519-129

Hailbronner, Michaela. 2014. "Rethinking the Rise of the German Constitutional Court: From anti-Nazism to value formalism". International Journal of Constitutional Law 12(3): 626649. DOI: https://doi.org/10.1093/icon/mou047

Hailbronner, Michaela. 2015. Traditions and Transformations. The Rise of German Constitutionalism. Oxford: Oxford University Press. DOI: https://doi.org/10.1093/acprof: oso/9780198735427.001.0001

Hennis, Wilhelm. [1968] 1978. "Verfassungsrecht und Verfassungswirklichkeit. Ein deutsches Problem". In Verfassung, edited by Manfred Friedrich, 232-267. Darmstadt: Wissenschaftliche Buchgesellschaft.

Herbert, Ulrich. 2006. "Integration der jungen Bundesrepublik durch Verfassungsrecht?" In Das Bonner Grundgesetz. Altes Recht und neue Verfassung in den ersten Jahrzehnten der Bundesrepublik Deutschland (1949-1969), edited by Michael Stolleis, 85-102. Berlin: Berliner Wissenschaftsverlag.

Hesse, Konrad. [1959] 1978. "Die normative Kraft der Verfassung". In Verfassung, edited by Manfred Friedrich, 77-99. Darmstadt: Wissenschaftliche Buchgesellschaft.

Holmes, Stephen. 1995. Passions and Constraints: On the Theory of Liberal Democracy. Chicago: University of Chicago Press.

Huscroft, Grant, Bradley W. Miller, and Grégoire Webber (eds.). 2014. Proportionality and the Rule of Law: Rights, Justification, Reasoning. Cambridge: Cambridge University Press. DOI: https://doi.org/10.1017/CBO9781107565272

Kneip, Sascha. 2016. "The Impact of the German Federal Constitutional Court on Consolidation and Quality of Democracy". In Constitutional Courts in Comparison. The US Supreme Court and the German Federal Constitutional Court, edited by Ralf Rogowski, and Thomas Gawron, 254-281. New York/Oxford: Berghahn Books.

Kommers, Donald P. 2002. "Comparative Constitutional Law: Its Increasing Relevance". In Defining the Field of Comparative Constitutional Law, edited by Vicki C. Jackson, and Mark Tushnet, 61-70. Westport (Conn.)/London: Praeger Publishing.

Kommers, Donald P., and Russell A. Miller. 2012. The Constitutional Jurisprudence of the Federal Republic of Germany. 3rd edition. Durham/London: Duke University Press. DOI: https://doi.org/10.1215/9780822395386

Korioth, Stefan. 2000. "Rudolf Smend". In Weimar: A Jurisprudence of Crisis, edited by Arthur J. Jacobson, and Bernhard Schlink, 207-248. Berkeley: University of California Press.

Kumm, Mattias. 2006. "Who is afraid of the total constitution? Constitutional Rights as Principles and the Constitutionalization of Private Law". German Law Journal 7(4): 341-369. DOI: https://doi.org/10.1017/S2071832200004727

Kumm, Mattias. 2007. "Political Liberalism and the Structure of Rights: On the Place and Limits of the Proportionality Requirement". In Law, Rights and Discourse: The Legal Philosophy of Robert Alexy, edited by George Pavlakos, 131-166. London: Hart Publishing.

Landfried, Christine. 1994. "The Judicialization of Politics in Germany". International Political Science Review 15(2): 113-124. DOI: https://doi.org/10.1177/019251219401500203

Leibholz, Gerhard. 1957. "Einleitung". In Der Status des Bundesverfassungsgerichts. Eine Materialsammlung mit einer Einleitung von Gerhard Leibholz, edited in Jahrbuch des Öffentlichen Rechts Neue Folge 6: 110-119.

Leibholz, Gerhard. 1974. "Das Bundesverfassungsgericht im Schnittpunkt von Politik und Recht". Deutsches Verwaltungsblatt, 396-399. 
Lepsius, Oliver. 2011. "Die maßstabsetzende Gewalt". In Das entgrenzte Gericht. Eine kritische Bilanz nach sechzig Jahren Bundesverfassungsgericht, edited by Matthias Jestaedt, et al., 159-279. Berlin: Suhrkamp.

Lepsius, Oliver. 2012. "Kritik der Dogmatik". In Was weiß Dogmatik? Was leistet und wie steuert die Dogmatik des Öffentlichen Rechts, edited by Gregor Kirchhof, Stefan Magen, and Karsten Schneider, 39-62. Tübingen: Mohr Siebeck.

Loewenstein, Karl. 1951. "Verfassungsrecht und Verfassungsrealität. Beiträge zur Ontologie der Verfassungen". Archiv des Öffentlichen Rechts 77: 387-435.

Lübbe-Wolff, Gertrude. 2016. "Die Verfassung als Wertordnung - Was heißt das?". Merkur 70(801): 47-54.

Maus, Ingeborg. 2004. "Vom Rechtsstaat zum Verfassungsstaat. Zur Kritik juridischer Demokratieverhinderung". Blätter für deutsche und internationale Politik 49(7): 835850.

Mathews, Jud, and Alec Stone Sweet. 2011. "All Things in Proportion? American Rights Review and the Problem of Balancing". Emory Law Journal 60(797): 797-875.

Möllers, Christoph. 2014. "The Scope and Legitimacy of Judicial Review in German Constitutional Law: Report on a missing debate". In Debates in German Public Law, edited by Hermann Pünder, and Christian Waldhoff, 3-25. London: Hart Publishing.

Morlok, Martin. 2006. "Art. Verfassung". In Evangelisches Staatslexikon. Neuausgabe, edited by Werner Heun, et al., 2556-2562. Stuttgart: Kohlhammer.

Müller, Jan-Werner. 2007. Constitutional Patriotism. Princeton: Princeton University Press.

Müller, Jan-Werner. 2011. Contesting Democracy. Political Ideas in Twentieth-Century Europe. New Haven: Yale University Press.

Münkler, Herfried. 2010. Mitte und Maß. Der Kampf um die richtige Ordnung. Berlin: Rowohlt.

Ooyen, Robert Chr. Van. 2008. "Die Integrationslehre von Rudolf Smend und das Geheimnis ihres Erfolgs in Staatslehre und politischer Kultur nach 1945". Journal der Juristischen Zeitgeschichte 2(2): 52-57.

Rensmann, Thilo. 2006. "The Constitution as Normative Order of Values: The Influence of International Human Rights Law on the Evolution of Modern Constitutionalism". In Völkerrecht als Wertordnung/Common Values in International Law, edited by Pierre-Marie Dupuy, et al., 259-278. Kehl/Strasbourg/Arlington: N. P. Engel Verlag.

Schlink, Bernhard. 2007. "Abschied von der Dogmatik. Verfassungsrechtsprechung und Verfassungsrechtswissenschaft im Wandel". Juristenzeitung 62(4): 157-162. DOI: https://doi. org/10.1628/002268807780223230

Schmitt, Carl. [1979] 2018. The Tyranny of Values and other Texts. Candor: Telos Press Publishing.

Schönberger, Christoph. 2011. "Der Aufstieg der Verfassung: Zweifel an einer geläufigen Triumphgeschichte. In Der Eigenwert des Verfassungsrechts. Was bleibt von der Verfassung nach der Globalisierung?, edited by Thomas Vesting, and Stefan Korioth, 7-22. Tübingen: Mohr Siebeck.

Schönberger, Christoph. 2015. Der "German Approach". Die deutsche Staatsrechtslehre im Wissenschaftsvergleich. Tübingen: Mohr Siebeck.

Smend, Rudolf. [1928] 2010. "Verfassung und Verfassungsrecht". In Staatsrechtliche Abhandlungen. 119-276. Berlin: Duncker \& Humboldt.

Somek, Alexander. 2014. The Cosmopolitan Constitution. Oxford: Oxford University Press.

Stolleis, Michael. 2005. "Die Staatsrechtslehre der fünfziger Jahre". In Das Lüth-Urteil aus (rechts-)historischer Sicht. Die Konflikte um Veit Harlan und die Grundrechtsjudikatur des Bundesverfassungsgerichts, edited by Thomas Henne, and Arne Riedlinger, 293-300. Berlin: Berliner Wissenschaftsverlag. 
Sweet, Alec Stone, and Jud Mathews. 2008. "Proportionality Balancing and Global Constitutionalism". Columbia Journal of Transnational Law 47(1): 73-165.

Tschentscher, Axel. 2014. "Interpreting Fundamental Rights - Freedom v. Optimisation". In Debates in German Public Law, edited by Hermann Pünder, and Christian Waldhoff, 43-56. London: Hart.

Tushnet, Mark. 2000. Taking the Constitution away from the Courts. Princeton: Princeton University Press. DOI: https://doi.org/10.1515/9781400822973

Vinx, Lars (ed.). 2015. The Guardian of the Constitution. Hans Kelsen and Carl Schmitt on the Limits of Constitutional Law. Cambridge: Cambridge University Press. DOI: https://doi. org/10.1017/CBO9781316136256

Volkmann, Uwe. 2013. Grundzüge einer Verfassungslehre der Bundesrepublik Deutschland. Tübingen: Mohr Siebeck.

Voßkuhle, Andreas. 2016. Die Verfassung der Mitte. München: Carl Friedrich von Siemens Stiftung.

Waldron, Jeremy. [2009] 2016. Political Political Theory. Cambridge (Mass.): Harvard University Press.

Weber, Werner. 1949. Weimarer Verfassung und Bonner Grundgesetz. Göttingen 1949. DOI: https://doi.org/10.1515/juru.1949.1949.10.302

How to cite this article: Frick, Verena. 2019. "The Justicization of Politics: Constitutionalism and Democracy in Germany after 1949." Redescriptions: Political Thought, Conceptual History and Feminist Theory 22(1): 18-34. DOl: https://doi.org/10.33134/rds.312

Submitted: 31 October 2019 Accepted: 31 October 2019 Published: 03 December 2019

Copyright: ( 2019 The Author(s). This is an open-access article distributed under the terms of the Creative Commons Attribution 4.0 International License (CC-BY 4.0), which permits unrestricted use, distribution, and reproduction in any medium, provided the original author and source are credited. See http://creativecommons.org/licenses/by/4.0/.

\section{Redescriptions: Political Thought, Conceptual History and}

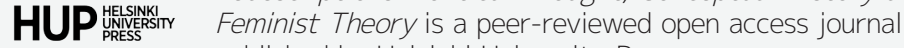
published by Helsinki University Press. 